\title{
PENGELOLAAN BUMDES CIKAHURIPAN MAJU BERBASIS EKONOMI SYARIAH
}

\author{
Yosi Mardoni ${ }^{\star}$, M. Fuad Hadziq, Arief Rahman Susila, Suhartono \\ Email: yosimardoni@ecampus.ut.ac.id $\left.{ }^{*}\right)$
}

\begin{abstract}
The rural sector is a sector that must be a major concern. This sector has the opportunity to develop and have a positive impact on the village economy if it is optimized. One of the spearheads of the village in advancing its economy is Village-Owned Enterprises (BUMDes). The existence of BUMDes is expected to be one of the incentives for rural economic growth. The role of the Sharia economy in advancing the rural sector has provided many examples of success. One of the most phenomenal is the grameen bank in Bangladesh. The purpose of this service activity is to revive the rural sector, especially human resources in BUMDEs. The method used is by conducting training and guidance. It is hoped that the guidance training method can strengthen the understanding of BUMDes human resources on the principles of Islamic economics. The application of Islamic economic principles in the implementation of BUMDes is expected to foster positive values which will provide blessings in the BUMDes business.
\end{abstract}

Keywords: BUMDes Management, Sharia Economy, Training

\begin{abstract}
ABSTRAK
Sektor pedesaan merupakan sektor yang harus menjadi perhatian utama. sektor ini memiliki peluang untuk dapat berkembang dan memberikan dampak positif bagi perekonomian desa apabila mampu dioptimalkan. Salah satu ujung tombak desa dalam memajukan perekonomiannya adalah Badan Usaha Milik Desa (BUMDes). Adanya BUMDes diharapkan menjadi salah satu rangsangan untuk pertumbuhan ekonomi desa. Peran ekonomi Syariah dalam memajukan sektor pedesaan sudah memberikan banyak contoh keberasilan. Salah satunya yang paling fenomenal adalah Grameen bank yang ada di Bangladesh. Tujuan dari kegiatan pengabdian ini adalah untuk membangkitkan sektor pedesaan khususnya sumber daya insani di BUMDEs. Metode yang dilakukan adalah dengan melakukan pelatihan dan bimbingan. Diharapkan dengan metode pelatihan bimbingan dapat memperkuat pemahaman sumber daya insani BUMDes akan prinsip ekonomi Syariah. Penerapan prinsip ekonomi Syariah dalam pelaksanaan BUMDes diharapkan dapat menumbuhkan nilai nilai positif yan akan memberikan keberkahan dalam usaha BUMDes.
\end{abstract}

Kata kunci: Pengelolaan BUMDes, Ekonomi Syariah, Pelatihan 


\section{PENDAHULUAN}

Peran ekonomi Islam dalam perekonomian sangat memiliki pengaruh yang cukup besar. Ekonomi Islam perlu diterapkan dan ditingkatkan eksistensinya karena manfaatnya yang luar biasa dalam mengatasi permasalahan bangsa dibandingkan dengan menerapkan sistem ekonomi konvensional yang justru menjerat dan membenani masyarakat, khususnya 'wong cilik'. Banyak kasus masyarakat yang terlilit hutang oleh rentenir menambah suram potret ekonomi konvensional. Badan Usaha Milik Desa (Bumdes) sebagi salah satu ujung tombak desa harus mampu menjawab permasalahan ini. Kegiatan usaha berdasarkan prinsip syariah tidak hanya memberi keuntungan yang bersifat duniawi namun ada dimensi ukhrowi juga. Keberkahan dan ketenangan dalam menjalanan usaha menjadi hasil paling penting bila ekonomi syariah dterapkan. Pembangunan Ekonomi menjadi salah satu cara untuk meningkatkan kesejahteraan nasional. Desa merupakan agen pemerintah terdepan untuk melaksanakan pembangunan ekonomi. Desa menjadi agen pemerintah yang secara langsung berkenaan dengan masyarakat (Bambang, 2017)

Sektor pedesaan merupakan sektor yang paling menonjol. sektor ini masih banyak memiliki peluang untuk berkembang dan masih memiliki dampak positif bagi perekonomian bila memang mampu dioptimalkan sesuai peraturan perundang-undangan yang ada (Dzikrulloh, 2016). BUMdes sebagai ujung tombak ekonomi desa memiliki kondisi yang berbeda-beda tergantung pada latar belakang dari pendirian BUMDes serta karakter dari masyarakatnya (Kusuma dan Purnamasari, 2016). Namun dalam prakteknya banyak pengelolaan BUMDes tidak berjalan dengan baik, sehingga BUMDes hanya sebatas papan nama saja (Ramadana et al., 2013)

Kampung Gunung Calincing desa Kuripan termasuk dalam wilayah administratif Kecamatan Ciseeng Kabupaten Bogor. Memiliki perangkat desa, 17 Rukun Tetangga (RT), 5 Rukun Warga dan 3 Dusun/kemandoran. Desa Kuripan jumlah terdiri dari 3 dusun jumlah penduduk sekitar 2700 jiwa. Sarana pelayanan Publik ibadah masjid 2, mushalah 4 majelis taklim 6. PAUD 1. SDN 1 dan SMPN 1 Ciseeng, pendukung sarana kesehatan Posyandu 4. Penduduk Warga masyarakat yang bekerja sebagai petani, buruh tani dan tukang serta pekerja rumah tangga (bekerja di rumah), batas wilayah sebelah utara Kali Curug Goong, sebelah Timur desa Cibentang. selatan wilayah Cibentang, barat Desa Kuripan, batas DAS Cisadane sekitar 0,5-2 KM, Jarak tempuh dari lokasi mitra ke Kabupaten Pemda Cibinong $40 \mathrm{~km}$. Adapun kegiatan pemerintahan didukung oleh urusan, pemerintahan, umum, keuangan kesra dan ekbang. Adapun Latar belakang pendidikan di desa Kuripan adalah seperti pada Tabel 1.

Tabel 1. Latar Belakang Pendidikan di Desa Kuripan

\begin{tabular}{lrr}
\hline Tingkatan Pendidikan & Laki-Laki & Perempuan \\
\hline Usia 3-6 tahun (belum masuk TK) & 206 orang & 202 orang \\
Usia 7-18 tahun yang sedang sekolah & 154 orang & 124 orang \\
Tamat SD/sederajat & 3.454 orang & 3.461 orang \\
Tamat SMP/sederajat & 618 orang & 320 orang \\
Tamat SMA/sederajat & 329 orang & 129 orang \\
Tamat D-2/sederajat & 8 orang & 4 orang \\
Tamat D-3/sederajat & 6 orang & 0 orang \\
Tamat S-1/sederajat & 8 orang & 3 orang \\
Tamat S-2/sederajat & 1 orang & 0 orang \\
\hline
\end{tabular}

Sumber: Laporan Desa Kuripan, 2016

Dari data pada Tabel 1 dapat dilihat bahwa, SDM di desa Kuripan sangat minim. Tabel 1 memperlihatkan bahwa lulusan S1 hanyalah 11 orang, Diploma III sebanyak 6 orang dari jumlah penduduk desa sejumlah 9.027 jiwa penduduk. Dari Tabel 1 juga dapat disimpulkan bahwa tingkat pendidikan paling besar yang ada dilingkungan desa Kahuripan adalah tamat SD/sederajat. Hal ini 
tentu membutuhkan tantangan yang lebih besar bagi pengelola BUMDes untuk melakukan kegiatan pemberdayaan.

Pemberdayaan sumberdaya manusia (SDM) dan ekonomi menjadi tantangan yang paling berat dalam menghadang arus globalisasi. Perubahan dalam semua segi kehidupan terutama sosial dan budaya begitu cepat dan mendasar yang menuntut sikap mental yang kuat serta produktivitas hidup hidup. Segala perubahan yang terjadi akan mampu dihadapi oleh SDM yang berkualitas dan Tangguh. Pengelolaan usaha secara tradisional masih menjadi permasalahan dari sisi manajemen bisnis. Rendahnya kemampuan pemasaran, akses ke sumber informasi, serta penyajian data keuangan dan akuntansi yang masih sederhana jauh jauh dari Pernyataan Standar Akutansi Keuangan (PSAK), serta penerapan teknologi yang masih minim menjadi permasalahan lain yang harus dibenahi.

Jika dilihat pada sisi permodalan, permasalahan yang masih terjadi pada umumnya adalah kapasitas permodalan sendiri yang masih terbatas (dana lebih dikonsentrasikan untuk pengembangan Bumdes). BUMDes ini banyak dilirik oleh bank konvensional sebagai mitra dalam penyaluran dana karena kondisi desa Cikuripan Ciseeng, memang sangat rawan prektek bank kelilling (praktek riba). Adanya BUMDes diharapkan mampu menjadi solusi untuk permasalahan praktek riba. Namun tentunya BUMDes harus memiliki konsep Ekonomi Syariah yang matang, agar prakteknya nanti sesuai dengan ekonomi syariah. Konsep syariah adalah konsep yang sudah teruji di saat krisis ekonomi. Untuk itulah dirasakan perlunya pelatihan pengelolaan BUMDes ini berbasis ekonomi syariah. Dengan konsep pengelolaan BUMDes berdasarkan prinsip syariah diharapkan usaha BUMDes lebih maju dan pastinya mendatangkan berkah. Setelah melakukan mapping daerah dalam pemetaan di sekitar Tangerang Selatan. Dari hasil tersebut didapat beberapa hal sebagai berikut:

1. Lebih dari $50 \%$ lahan sudah banyak dimiliki oleh pihak luar (PT).

2. Pengelolaan masih sangat sederhana dan terbatas SDM nya.

3. Banyak rentenir dan bank illegal dengan bunga tinggi.

4. Kondisi ekonomi masyarakat yang cenderung pra-sejahtera.

5. Tingkat pengangguran tinggi pada usia kerja.

Pada umumnya permasalahan usaha mikro, kecil dan menengah termasuk BUMDes memiliki berbagai kendala klasik, seperti permasalahan sumber daya manusia, manajemen bisnis, legalitas formal dan tentu saja permodalan. Dari sisi sumber daya manusia permasalahan yang terjadi adalah perlunya peningkatan kualitas dan daya saing SDM pengelola Unit-unit Usaha Bumdes dibanding unit usaha yang lain, kurangnya dukungan pelatihan sehingga analisa kelayakan usaha dan pengembangan bisnis masih tertinggal dan mayoritas belum memikirkan peluang untuk melakukan kerjasama dengan unit usaha di Bumdes yang lain. Keterbatasan jenis usaha yang dilakukan BUMDes dan keterbatasan sumberdaya manusia dalam pengelolaan BUMDes serta rendahnya partisipasi masyarakat karena minimnya pengetahuan membuat tujuan BUMDes dalam peningkatan ekonomi belum berjalan maksimal (Agunggunanto, 2016). Berdasarkan analisis terhadap permasalahan yang ada maka kegiatan pengabdian kepada masyarakat ini perlu untuk dilaksanakan.

\section{METODE PELAKSANAAN}

Metode yang digunakan dalam program pengabdian masyarakat ini adalah Metode pelatihan. Pelatihan akan dilakukan selama dua kali dengan rincian sebagai berikut:

1. Melakukan pelatihan mengenai pengenalan ekonomi dan bisnis syariah, akad-akad transaksi syariah.

2. Melakukan pelatihan mengenai, dasar-dasar lembaga keuangan syariah, manajemen operasional lembaga keuangan syariah (akad dan Produk LKS).

Model atau metode pelakasanaan dalam kegiatan pengabdian kepada masyarakat yang dilakukan adalah sebagai berikut: 


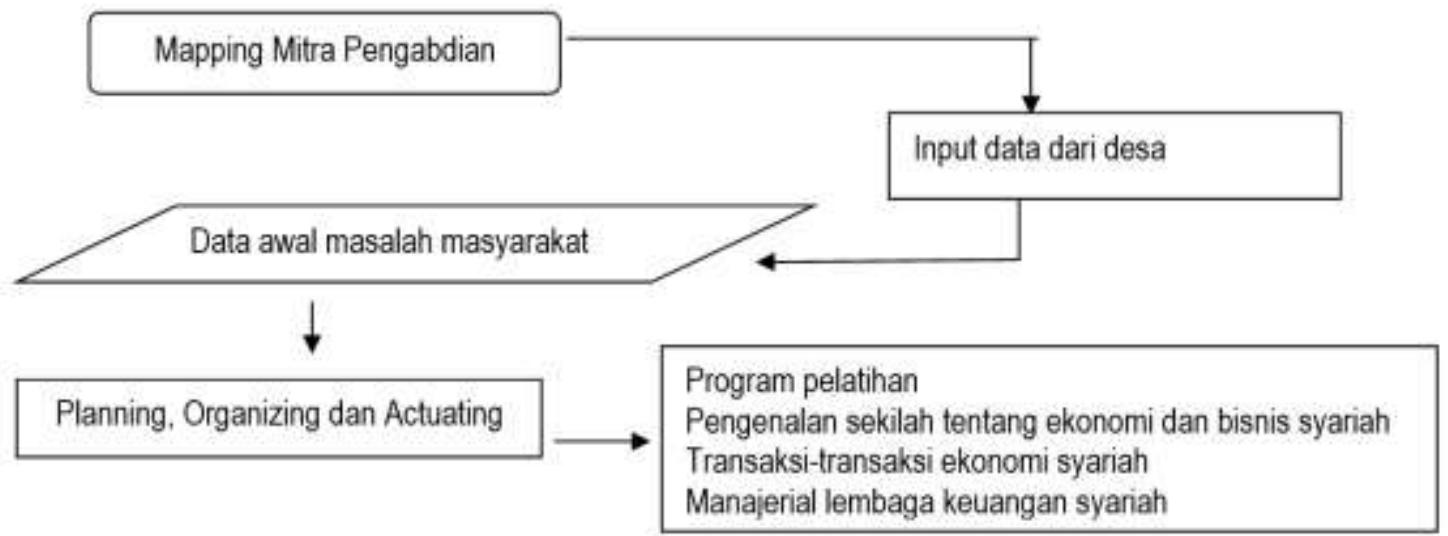

Gambar 1. Model atau metode pelakasanaan dalam kegiatan Pengabdian Kepada Masyarakat

\section{Prosedur Kerja dan Rencana Kegiatan}

Untuk memudahkan pelaksanan kegiatan pengabdian kepada masyarakat ini maka disusunlah prosedur kerja dan rencana kegitan sebagai berikut:

Tabel 2. Prosedur Kerja dan Rencana Kegiatan

\begin{tabular}{|c|c|c|}
\hline Tahapan & Aktivitas & Keterangan \\
\hline Pemetaan area & $\begin{array}{l}\text { Observasi langsung ke lapangan kegiatan } \\
\text { Melakukan wawancara dengan Pengurus } \\
\text { BUMDes }\end{array}$ & $\begin{array}{l}\text { Pemetaan kegiatan } \\
\text { Pengumpulan data awal di } \\
\text { objek pengabdian }\end{array}$ \\
\hline $\begin{array}{l}\text { Analisis kebutuhan } \\
\text { masyarakat }\end{array}$ & Pengumpulan informasi awal masyarakat & $\begin{array}{l}\text { Data terkait kebutuhan } \\
\text { masyarakat }\end{array}$ \\
\hline $\begin{array}{l}\text { Penentuan } \\
\text { peserta pelatihan }\end{array}$ & Pemilihan peserta oleh pengurus masyarakat & Anggota masyarakat \\
\hline Pre-tes materi 1 & $\begin{array}{l}\text { Menyebarkan kuesioner untuk melihat } \\
\text { pemahaman masyarakat tentang ekonomi dan } \\
\text { bisnis syariah }\end{array}$ & Semua peserta pelatihan \\
\hline \multirow{2}{*}{$\begin{array}{l}\text { Pelatihan } \\
\text { pengenalan } \\
\text { ekonomi dan } \\
\text { bisnis syariah, } \\
\text { transaksi syariah }\end{array}$} & $\begin{array}{l}\text { Presentasi dan tanya jawab tentang pengertian } \\
\text { dan transaksi dalam ekonomi syariah }\end{array}$ & \multirow{2}{*}{$\begin{array}{l}\text { Pelaksanaan pelatihan } \\
\text { dilakukan dalam waktu } \\
\text { seharian dengan beberapa } \\
\text { tahapan pelatihan }\end{array}$} \\
\hline & Pelaksanaan pelatihan kegiatan & \\
\hline Evaluasi pelatihan & Evaluasi terhadap hasil pelatihan & Semua peserta pelatihan \\
\hline $\begin{array}{l}\text { Pre-tes materi hari } \\
\text { ke-2 }\end{array}$ & $\begin{array}{l}\text { Menyebarkan kuesioner untuk melihat } \\
\text { pemahaman masyarakat tentang manajerial } \\
\text { lembaga keuangan syariah }\end{array}$ & Semua peserta pelatihan \\
\hline $\begin{array}{l}\text { Pelatihan } \\
\text { Manjerial lembaga } \\
\text { keuangan syariah }\end{array}$ & $\begin{array}{l}\text { Presentasi dan tanya jawab tentang pengertian } \\
\text { dan transaksi dalam ekonomi syariah }\end{array}$ & $\begin{array}{l}\text { Pelaksanaan pelatihan } \\
\text { dilakukan dalam waktu } \\
\text { seharian }\end{array}$ \\
\hline
\end{tabular}




\begin{tabular}{lll}
\hline Tahapan & Aktivitas & Keterangan \\
\hline Evaluasi pelatihan & Evaluasi terhadap hasil pelatihan & Semua peserta pelatihan \\
$\begin{array}{l}\text { Pembuatan } \\
\text { laporan }\end{array}$ & $\begin{array}{l}\text { Penyusunan laporan akhir pelatihan dan } \\
\text { pemberdayaan masyarakat }\end{array}$ & $\begin{array}{l}\text { Laporan disusun sesuai } \\
\text { dengan kondisi hasil serta } \\
\text { panduan UT }\end{array}$ \\
$\begin{array}{l}\text { Luaran panduan } \\
\text { pelatihan }\end{array}$ & Penyusunan panduan pelatihan & \\
\hline
\end{tabular}

\section{HASIL DAN PEMBAHASAN}

Pelaksanaan Kegiatan Pengabdian kepada Masyarakat dapat dikelompokkan dalam beberapa kegitaan seperti yang terlihat pada Tabel 3 .

Tabel 3. Pelaksanaan Kegiatan Pengabdian kepada Masyarakat

\begin{tabular}{|c|c|}
\hline Kegiatan & Pelaksana \\
\hline $\begin{array}{l}\text { Survey pendahuluan dan } \\
\text { pemetaan kebutuhan }\end{array}$ & Tim Abdimas \\
\hline $\begin{array}{l}\text { Pelaksanaan Abdimas } \\
\text { Tahap I yang meliputi } \\
\text { kegiatan: } \\
\text { 1. Pelatihan sekilas tentang } \\
\text { ekonomi dan bisnis } \\
\text { syariah. }\end{array}$ & $\begin{array}{l}\text { Tim Abdimas } \\
\text { Kegiatan ini diikuti oleh Pengurus dan pengelola BUMDes } \\
\text { sebanyak } 7 \text { orang }\end{array}$ \\
\hline $\begin{array}{l}\text { 2. Pelatihan dalam } \\
\text { manajerial Lembaga } \\
\text { Keuangan syariah }\end{array}$ & $\begin{array}{l}\text { Tim Abdimas } \\
\text { Kegiatan ini diikuti oleh Pengurus dan pengelola BUMDes } \\
\text { sebanyak } 7 \text { orang }\end{array}$ \\
\hline $\begin{array}{l}\text { 3. transaksi-transaksi di } \\
\text { dalam ekonomi Syariah. }\end{array}$ & $\begin{array}{l}\text { Tim Abdimas } \\
\text { Kegiatan ini diikuti oleh pengelola BUMDes sebanyak } 2 \\
\text { orang dari tim pengelola BUMDes }\end{array}$ \\
\hline Monev & Tim Abdimas \\
\hline
\end{tabular}

Kegiatan ini bernama pengelolaan BUMDes Cikahuripan maju berbasis ekonomi syariah dalam bentuk sosialisasi dan pelatihan dilakukan ini dilakukan sebanyak dua kali. Kegiatan pelatihan pertama dilaksanakan tanggal 12 Agustus 2018 di Desa Kuripan Ciseeng berupa Pelatihan dan atau pemberian pemahaman terkait pengelolaan BUMDes sesuai dengan prisip dan kaidah Syariah.

Adapun materi pelatihan yang disampaikan terdiri dari:

1. Pelatihan sekilas tentang ekonomi dan bisnis syariah.

2. Pelatihan dalam manajerial Lembaga Keuangan Syariah

Materi pelatihan disampaikan oleh dosen program studi ekonomi Syariah Universitas Terbuka. Pelatihan ini bertujuan untuk memberikan dasar pemahaman terkait ekonomi Syariah kepada para pengurus dan pengelola BUMDes. Pelatihan kedua dilakukan pada tanggal 9 Oktober 2018. Pada pelatihan kedua ini pengelola BUMDes yang dilatih terdiri dari dua orang yaitu: Bapak Ahmad Sudrajat dan Ibu lin Asmawati. Pada pertemuan ini peserta diberikan pelatihan terkait transaksi-transaksi di dalam ekonomi Syariah. 
Selama proses pelaksanaan pengabdian masyarakat tidak terdapat kendala yang berarti. Peserta sangat antusias mengikuti pelatihan yang diadakan oleh tim abdimas Universitas Terbuka. Terlihat banyak peserta yang memberikan pertanyaan. Beberapa kendala kecil seperti sulitnya menyesuaikan waktu rapat menjadi permasalahan minor yang dapat segera diatasi. Informasi yang disampaikan ke peserta pun dapat dilakukan dengan mudah. Untuk materi pemahaman ekonomi Syariah dapat ditangkap dengan mudah oleh peserta. Namun terkait pelatihan transaksi-transaksi agak kesulitan, karena banyak istilah-istilah dalam ekonomi Syariah yang belum familiar bagi peserta. Peserta pelatihan telah dibekali dengan buku pedoman pengelolaan organisasi secara ekonomi Syariah.

\section{Foto Kegiatan Pelaksanaan Pengadian kepada Masyarakat}

\begin{tabular}{|l|l|}
\hline & $\begin{array}{l}\text { Salah Satu usaha BUMdes yang sudah berjalan dengan } \\
\text { baik, yaitu isi ulang air minum }\end{array}$ \\
\hline Barang-barang untuk dijual masih tergelak dilantai dan \\
\hline tidak tertata dengan baik
\end{tabular}




\section{SIMPULAN}

Badan Usaha Milik Desa sebagai ujung tombak ekonomi desa diharapkan mampu menjadi pemantik untuk meningkatkan kesejahteraan ekonomi masyarakat desa. Peran ini tentunya harus mendapatkan dukungan dari pemerintah pusat dan seluruh perangkat desa. Dalam kegiatan pengabdian kepada masyarakat ini dapat disimpulkan bahwa penerapan akad-akad Syariah dalam pengelolaan BUMDes dapat dilakukan. Diharapkan dengan penerapan prinsip prinsip ekonomi Syariah dalam pengelolaan BUMDes ini menjadikan pelayanan dan kinerja BUMDes menjadi lebih baik dalam mencapai kemaslahatan untuk masyarakat desa.

\section{REFERENSI}

Agunggunanto, Edy Yusuf. (2016). Pengembangan Desa Mandiri Melalui Pengelolaan Badan Usaha Miik Desa (BUMdes). Jurnal BISNIS, Vol. 4, No. 1, Juni 2016.

Bambang, B. (2017). Implemetasi Badan Usaha Milik Desa Berbasis Ekonomi Islam: Suatu Kajian Elementer. Jurnal lqtisaduna, 3(2), 109-131.

Dzikrulloh, D., \& Permata, A. R. E. (2016). Sinergitas Baitul Maal Wa Tamwil (BMT) Dengan Badan Usaha Milik Desa (BUMDES) Sebagai Alternatif Penguatan UMKM Masyarakat Pedesaan. Dinar Jurnal Ekonomi dan Keuangan Islam, 1(1).

Kusuma, Gabriella Hanny \& Nurul Purnamasari. (2016). BUMDES: Kewirausahaan Sosial yang Berkelanjutan (Analisis Potensi dan Permasalahan yang dihadapi Badan Usaha Milik Desa di Desa Ponjong, Desa Bleberan, dan Desa Sumbermulyo). Yayasan Penabulu.

Ramadana, Coristya Berlian, Heru Ribawanto, \& Suwondo. (2013). Keberadaan Badan Usaha Milik Desa (BUMDes) Sebagai Penguat Ekonomi Desa. Jurnal Administrasi Publik (JAP) Vol.1.No.6 Hal:1068-1076. ISSN: 2503- 3867. 